\title{
HERMENEUTYKA UMIERANIA
}

\author{
Śmierć nie chce być zrozumiana. \\ To, co w niej zrozumiate, to tylko część śmierci, \\ li̇ejsza, należaca do życia, niemal przezroczysta. \\ Adam Zagajewski, Maty Larousse
}

Hermeneutyka umierania powstaje w bardzo „ludzkim”, jednocześnie pokornym i ciekawskim, odruchu wobec niedostępności hermeneutyki śmierci. Myśl hermeneutyczna powraca tu do swoich źródeł i oprócz nastawienia na rozumienie, próbuje określić też warunki możliwości tegoż rozumienia, a także - to ów „ludzki” element - wydrzeć inteligibilną cząstkę temu, co zrozumiane być nie może lub nie chce - tajemnicy śmierci. Celem niniejszego tekstu jest krytyczny przegląd wybranych filozoficznych, socjologicznych i literackich propozycji możliwości ujęcia, pojęcia czy jakiejś formy doświadczenia śmierci.

Wyjściowe założenie, oparte nie tylko na lekturze tekstów, których omówienie dopiero nastąpi, ale i na pewnym powszechnym przekonaniu, mówi, że tym, co hermeneutyczne spojrzenie jest w stanie $\mathrm{w}$ śmierci uchwycić, jest proces umierania, nie zaś stan śmierci (abstrahuję tu, wskutek braku kompetencji, od takich wątków jak śmierć kliniczna czy właściwe przeżyciom mistycznym stany supra semet ipsum). Tym samym - to kolejna przeszkoda - to, co ma być poznane, nieustannie staje się, czy, jakby powiedział Heidegger - istoczy się, nigdy zaś nie jest.

Założenie to nie oznacza milczącej zgody na słynną maksymę Epikura z Listu do Menoikeusa: „,śmierć, najstraszniejsze z nieszczęść, wcale nas nie dotyczy, bo gdy my istniejemy, śmierć jest nieobecna, a gdy tylko śmierć się pojawi, wtedy nas już nie ma"1, albowiem z równania tego usunięta zostaje

${ }^{1}$ Cyt. za: Diogenes Laetrios, Żywoty i poglądy stynnych filozofów, przeł. I. Krońska, K. Leśniak, W. Olszewski, Państwowe Wydawnictwo Naukowe, Warszawa 1982, s. 545. 
nie tylko świadomość pewności śmierci jako elementu życia, swoisty egzystencjał, ale też pewne paradoksalne i z definicji niedoskonałe anty-doświadczenie śmierci (doświadczenie nie-doświadczania, nie-doznawania), które może być dane $w$ antycypacji pod postacią odczucia, wrażenia. Tym samym owa niemożność doświadczania niemożności doświadczania jest absolutna filozoficznie, ale już nie egzystencjalnie.

Tytułowa bohaterka powieści Johna Maxwella Coetzee Elizabeth Costello stwierdza: „Potrafię sobie wyobrazić przez sekundę (...) jak to jest, kiedy się jest trupem. To wyobrażenie budzi we mnie odrazę. Przepełnia mnie grozą, uciekam przed nim, nie chcę go kontemplować" ${ }^{2}$. Trudno powiedzieć, na ile wrażenie to - właściwe $w$ tym wypadku postaci literackiej, a więc $i$, być może, jej twórcy, jak i piszącemu te słowa - można ekstrapolować na innych. Costello stwierdza, że nie chce „kontemplować” owego „wyobrażenia”. Czy oznacza to, że gdyby chciała, owo wyobrażenie mogłoby trwać dłużej niż tylko jako przelotny, nieprzyjemny impuls? Czy to rzeczywiście jej wola ucina to wyobrażenie, czy może jakiś ochronny mechanizm psychologiczny? Jakiekolwiek by nie padły odpowiedzi na to pytanie, użycie określenia „kontemplacja" dostarcza filozoficznej analizie podstaw do obnażenia uzurpatorstwa w tego typu "przebłysku siebie nieżywego". Wyobrażenie niebytu zakłada bowiem istnienie bytu, który owo wyobrażenie posiada, chwilowa pustka myśli i doznań momentalnie wypełniona zostaje treścią pod postacią trwogi, grozy czy odrazy, zaś nadbudowana nad tymi doznaniami świadomość ich doznawania jest nieusuwalnym elementem całej psychosomatycznej ekonomii doświadczania.

Najczęściej przywoływanym jako model śmierci egzystencjalnym komponentem doświadczenia jest sen (śmierć jako „wieczny” czy „wiekuisty sen”). Począwszy od Sokratesa (,jeśli [śmierć - przyp. P.J.] to brak wrażeń, jeśli to coś jak sen, kiedy ktoś śpiąc - nawet widziadeł nie ogląda żadnych..."3), przez Sanczo Pansę (,jedna tylko rzecz w śnie jest zła, iż - jak słyszałem - podobny jest do śmierci, bowiem niewielka jest różnica między człowiekiem śpiącym a umarłym”" ${ }^{\prime 4}$, na pielęgniarce z współczesnego oddziału paliatywnego skończywszy („mówię im [pacjentom - przyp. P.J.], że śmierć jest jak sen" ${ }^{5}$ ), to właśnie sen, moment, w którym rozum odpoczywa, jest dla tegoż rozumu rozpaczliwym i w jakiejś mierze pokrzepiającym

\footnotetext{
2 J.M. Coetzee, Elizabeth Costello, przeł. Z. Batko, Znak, Kraków 2006, s. 92.

3 Obrona Sokratesa, [w:] Eufryton, Obrona, Kriton, przeł. W. Witwicki, Państwowe Wydawnictwo Naukowe, Warszawa 1958, s. 129.

${ }^{4}$ M. de Cervantes Saavedra, Przemyślny szlachcic Don Kichote z Manczy, przeł. A.L. Czerny, Z. Czerny, Zielona Sowa, Kraków 2006, s. 694.

${ }^{5} \mathrm{~K}$. Kowalski, Mówię im, że śmierć jest jak sen (wywiad z Iwoną Cieślą, pielęgniarką na oddziale paliatywnym), "Tygodnik Powszechny” nr 7 z dn. 17.02.2007.
} 
ratunkiem przed granica, jaką stawia mu śmierć. Sen, lub ewentualnie W wersji mniej przyjaznej - nieprzytomność (nieświadomość) ${ }^{6}$. W ten sposób jednak mimochodem zadekretowana zostaje niemożność poznawcza, gdyż sen / nieprzytomność rozpoznawane są (wewnętrznie) jako takie jedynie ex post, po przebudzeniu / oprzytomnieniu, którego to w przypadku śmierci, jak wiadomo, brak i ta, jak to określił Sanczo, „niewielka” różnica okazuje się różnicą zasadniczą.

Hermeneutyką umierania operować może i powinna w sytuacji, w której zanika zarówno ujmowanie życia jako „jeszcze-nie” śmierci, jak i śmierci jako „już-nie” życia, zaś spotykają się ze sobą (na zasadzie tak agonicznej, jak i wzajemnego dopełniania się) „jeszcze” życia i „już” śmierci. Hermeneutykę umierania nad hermeneutykę śmierci wynosi również fakt, że w umieraniu obecny jest jeszcze „byt, który może być zrozumiany”, czyli - język (ciekawy zaiste przypadek pana Waldemara z opowiadania Edgara Alana Poe nie będzie mnie tu interesował).

W scenie umierania język pojawia się na co najmniej dwa sposoby: jako testament i jako pożegnanie (pozostałość dawnego błogosławieństwa). Testament, niegdyś sporządzany (lub wygłaszany) „na łożu śmierci”, obecnie, w epoce „społeczeństwa ryzyka”, przeważnie pisany jest uprzednio, „na wszelki wypadek", często na wiele lat wstecz (patrząc z perspektywy śmierci testatora). Pozostały jednak „ostatnie słowa”, , czarne kwiaty”, jak to określił Cyprian Kamil Norwid", wypowiadane już „znad grobu”, „ostatnim tchnieniem", w sekundzie zawieszenia między życiem a śmiercią. Ich obecność jest jednak również zagrożona wskutek stosowania obniżających świadomość umierania (będącą niejako warunkiem koniecznym autentyczności tych słów ${ }^{9}$ ) i łagodzących ból środków farmaceutycznych.

Po nich nie pojawia się jednak - jak pisze Giorgio Agamben - żaden „głos mogący dać wyraz zamilknięciu głosu"10. Nastąpić może jedynie zakończenie indywidualnego bytowania w języku pod postacią przerwania osobistego

${ }^{6}$ Zob. J. Bielas, Jak to jest stać się martwym. Doświadczenie śmierci - rekonstrukcja i analiza, [w:] K. Krzyżewski (red.), Doświadczenie indywidualne. Szczególny rodzaj poznania i wyróżniona postać pamięci, Wydawnictwo Uniwersytetu Jagiellońskiego, Kraków 2003, s. 106.

7 Zob. H.-G. Gadamer, Prawda i metoda. Zarys hermeneutyki filozoficznej, przeł. B. Baran, Inter Esse, Kraków 1993, s. 429.

8 Czarne kwiaty „wierne są jak podpisy świadków, którzy, pisać nie umiejąc, znakami krzyża niekształtnie nakreślonego pospisują się" (C.K. Norwid, Czarne kwiaty, <http://literat. ug.edu.pl/nproza/black.htm> [dostęp: 05.06.2012]).

9 „By (...) doświadczyć naprawdę własnej śmierci, trzeba być w momencie umierania i zdawać sobie z tego sprawę" (J.-V. Thomas, Doświadczenie śmierci: jego granice i rzeczywistość, przeł. J.M. Godzimirski, [w:] Antropologia śmierci. Myśl francuska, wybór i przeł. S. Cichowicz, J. M. Godzimirski, Wydawnictwo Naukowe PWN, Warszawa 1993, s. 163.

${ }^{10}$ G. Agamben, Co zostaje z Auschwitz. Archiwum i świadek (Homo sacer III), przeł. S. Królak, Wydawnictwo Sic!, Warszawa 2008, s. 35. 
dyskursu, niczym urwana melodia wykonywana przez trębaczy z wieży Kościoła Mariackiego, odtwarzająca symbolicznie moment trafienia legendarnego sygnalisty tatarską strzałą, jego ostateczne i gwałtowne zamilknięcie.

Byłbym skłonny mówić nawet o "tekście umierania”, odczytywanym przez towarzyszących umierającemu i odnoszonym przez nich antycypująco do nieuchronnej chwili własnej agonii. Faktem jest, że partycypacja i antycypacja (lub Heideggerowskie "wybieganie” - Vorlaufen) wyznaczają dwa podstawowe pola możliwości działania hermeneutyki umierania. Jak zostanie pokazane, śmierć „drugiego" czy „twoja śmierć”, czyli właśnie partycypacja, jest polem o wiele bardziej poznawczo płodnym niż śmierć „moja”, właściwa antycypacji. Zacznę jednak od tej drugiej.

W tekście, który z racji swego tytułu i nazwiska autora mógłby być podstawową lekturą hermeneutyki umierania, Doświadczeniu śmierci Hansa-Georga Gadamera, tematem jest jednak nie tyle tytułowe „doświadczanie”, co „zanikanie obrazu śmierci we współczesnym społeczeństwie”"11, czyli obszar badań określany przeważnie jako antropologia śmierci ${ }^{12}$, co wykracza poza ramy zarysowane dla niniejszego artykułu. Wszelako jedna uwaga Gadamera wydaje się ważna dla dalszych rozważań. Otóż filozof z lekkim przerażeniem spogląda na osiągnięcia techniki i farmakologii czynione w służbie nie tylko opieki paliatywnej, ale też podtrzymywania ludzkiego życia (czy raczej: funkcji życiowych) ponad jego „naturalną” miarę. Tym samym śmierć jest nie tylko odosobniona (usuwana z przestrzeni publicznej), ale też „odosobiona”. "Nowoczesna chemia, wyposażona w środki znieczulania, wywłaszcza cierpiącą osobę. (...) Wyłącza równocześnie tych, którzy przeżyli, z udziału, biernego i czynnego w tym wydarzeniu"13. Wyłania się z tego przekonanie, iż zarówno śmierć, jak i umieranie, są tym, co warto (świadomie) przeżyć (w sensie: doświadczyć), są integralnym i kluczowym elementem ludzkiego, a więc - rozumiejącego istnienia na świecie.

Inny tekst, który samym swoim tytułem obiecuje wiele dla projektu hermeneutyki umierania - O doświadczeniu śmierci Władysława Stróżewskiego - jest z kolei w większej swej części analizą motywu śmierci występującego literaturze ${ }^{14}$.

11 Zob. H.-G. Gadamer, Doświadczenie śmierci, przeł. A. Przyłębski, [w:] tenże, O skrytości zdrowia, Poznań 2011, s. 79.

12 Nazwa ta pochodzi od książki Anthropologie de la mort (Payot, Paris 1975) wspomnianego już Luisa-Vincenta Thomasa.

${ }^{13}$ H.-G. Gadamer, Doświadczenie śmierci, dz. cyt., s. 80-81. Luis-Vincent Thomas z kolei przytacza świadectwo chorego, któremu „lekarze przedłużali życie i który narzekał, że ukradziono mu jego agonię". Chory ów, odrzucając pomoc paliatywną, miał powiedzieć: „Nikt nie pozbawi mnie mojej śmierci” (J.-V. Thomas, Doświadczenie śmierci..., dz. cyt., s. 159).

${ }^{14}$ Zob. W. Stróżewski, O doświadczeniu śmierci, [w:] tenże, O wielkości. Szkice z filozofii człowieka, Znak, Kraków 2002, s. 133-157. Dziwić może fakt, że autor, skoro zakłada, że interesować 
Badacze wykazują zadziwiającą jednomyślność jeśli chodzi o możliwość rozumowego czy emotywnego ujęcia, za życia, własnej śmierci. „Śmierć nie jest doświadczeniem w życiu. Śmierci się nie doznaje"15 - pisał Ludwik Wittgenstein w Tractatus logico-philosophicus; o śmierci należałoby więc milczeć. Podobnie na tę kwestię zapatrywał się Zygmunt Freud w tekście Our Attitude Towards Death (Nasze nastawienie wobec śmierci):

w rzeczywistości nie potrafimy wyobrazić sobie naszej własnej śmierci; kiedykolwiek próbujemy to uczynić, odkrywamy, że przeżywamy samych siebie (survive ourselves) jako świadkowie ${ }^{16}$.

Martin Heidegger pisał z kolei, że „Śmierć jako możliwość nie daje jestestwu niczego »do urzeczywistnienia « i niczego, czym ono samo jako rzeczywiste mogłoby być. Jest ona możliwością niemożliwości wszelkiego odnoszenia się do..., wszelkiego egzystowania"17. Zygmunt Bauman zaś: „,jedyną rzeczą, której myśl nie może uchwycić, jest jej własne nieistnienie"18.

Śmierć - to już słowa Stanisława Cichowicza - jest zagadkową nazwą najważniejszej u człowieka z form skończoności, której jest on świadom w niewyraźnym przeczuciu i niejasnym doświadczeniu, ale której nie może sobie przedstawić. Jako zdarzenie śmierć jest ",gwałtem” zadawanym idei, „,czarną dziurą" na horyzoncie świadomości, "plamą" mającą przejrzystość przeżyć, a jako temat wypowiedzi odsłania się zaledwie w ruchu metafor ${ }^{19}$.

go będzie „śmierć drugiego", i gęsto cytuje poezję i prozę Rainera Marii Rilkego, nie odnosi się do jego wiersza zatytułowanego właśnie Doświadczenie śmierci, w którym poeta, stwierdzając wpierw poznawczą niemoc („O tych odejściach, których nasz los nie obchodzi, / nie wiemy nic"), mówi następnie o swoistego rodzaju metafizycznym doświadczeniu (używając współczesnej terminologii, można by określić je jako „uderzenie Realnego”), które powstaje przy towarzyszeniu bliskiej osobie w jej umieraniu: „Lecz gdyś odchodził, zabłysło na scenie / pasmo rzeczywistości przez tę szparę / gdzieś zniknął: zieleń prawdziwej zieleni / prawdziwy promień, las, któremu dałeś wiarę" (R.M. Rilke, Poezje, przeł. M. Jastrun, Wydawnictwo Literackie, Kraków 1987, s. 97).

${ }^{15}$ L. Wittgenstein, Tractatus logico-philosophicus, przeł. i wstępem opatrzył B. Wolniewicz, Wydawnictwo Naukowe PWN, Warszawa 2000, s. 81, teza 6.431.

16 Z. Freud, Our Attitude Towards Death, [w:] tenże, Reflections on War and Death, przeł. A.A. Brill, A.B. Kuttner, New York 1918, <http://www.bartleby.com/282/2.html> [dostęp: 03.01.2012]. Z obserwacji tej Freud wyciąga wniosek, iż „nikt nie wierzy we własną śmierć (...), w nieświadomości każdy jest przekonany o tym, że jest nieśmiertelny".

17 M. Heidegger, Bycie i czas, przeł. B. Baran, Wydawnictwo Naukowe PWN, Warszawa 1994, s. 368.

18 Z. Bauman, Śmierć i nieśmiertelność. O wielości strategii życia, przeł. N. Leśniewski, Wydawnictwo Naukowe PWN, Warszawa 1998, s. 21.

${ }^{19}$ S. Cichowicz, Śmierć: gwałt na idei lub reakcja życia, [w:] Antropologia śmierci..., dz. cyt., s. 9. Podobnie "ojciec tanatologii”, Luis-Vincent Thomas, pisze, że „póki żyjemy, śmierć istnieje dla nas tylko w obrazach, które sama sugeruje, oraz w językach, których używamy do jej opisania" (L.-V. Thomas, Tworzenie tanatologii, przeł. M.L. Kalinowski, [w:] Wymiary śmierci, wybór i wstęp S. Rosiek, słowo/obraz terytoria, Gdańsk 2002, s. 11). 
Owa „plama” o „przejrzystości przeżyć” kierowałaby hermeneutykę umierania w stronę Bachelardowskiej „poetyki marzenia”, przywołanie Friedricha Nietzschego w ostatnim zdaniu z kolei umieszcza śmierć (albo jej figuralny, w sensie - przeniesiony, obraz) jedynie na retorycznej płaszczyźnie języka. Jeśliby przyjąć te założenia, tym, co badane, nie będzie mogła być śmierć jako taka, lecz sposoby jej przedstawiania: nie "co" czy „o czym”, lecz „jak" się mówi / pisze.

Imperatyw dla języka mówienia o śmierci przedstawia Stanisław Rosiek:

Teologiczne, moralistyczne czy filozoficzne próby przybliżania się do śmierci i jej istoty to na ogół pusta gadanina, która jest nie do zniesienia zwłaszcza wtedy, kiedy stroi się w szaty wyszukanego stylu. Im piękniej, tym gorzej. Irytująca kaligrafia - wszystkie te piękne zdania o śmierci, błyskotliwe paradoksy, nienagannie skrojone aforyzmy. Jak najmniej stylu. Wobec spraw ostatecznych konieczna jest powściągliwość. Należy mówić mało i jak najprościej. Brzydko. Słowa o śmierci powinny wydzielać trupi odór ${ }^{20}$.

Zgodnie z tym przekonaniem, obecność śmierci w języku może objawić się jedynie na poziomie stylu, a jedyną treścią wypowiedzi, która jest w stanie śmierci dosięgnąć, jest ta będąca pochodną formalnego, językowego opracowania wypowiedzi. Zamiast pisania i „kaligrafii”, Rosiek proponuje raczej „lekturę" masek pośmiertnych lub - w odległym Lévinasowskim duchu twarzy umarłego. One bowiem „same potrafią odsłonić prawdę o śmierci i umieraniu - robią to bezpośrednio i z całą bezwzględnością, ja jaką je stać. Niepotrzebna im pomoc".

Mimo całego przedstawionego powyżej wielogłosu znajdują się i tacy badacze, którzy na rozmaite sposoby próbują przybliżyć człowiekowi jego własną śmierć, substancjalizować "czarną dziurę" znajdującą się na „horyzontu świadomości”. Racjonalna propozycja, którą przedstawia Thomas Nagel, jest, jeśli nawet dla kogoś przekonująca, z pewnością nie hermeneutyczna.

Nie możesz przedstawić sobie własnego nieistnienia od wewnątrz. Nie możesz sobie przedstawić, jak to jest być całkowicie unicestwionym, ponieważ od wewnątrz byłoby to niczym. (...) Nie możesz przedstawić sobie, jak to jest być pozbawionym świadomości, choćby na jakiś czas; to, że nie możesz przedstawić sobie tego od wewnątrz, nie znaczy, że w ogóle sobie tego nie możesz przedstawić. Musisz po prostu pomyśleć o sobie od zewnątrz, o sobie nieprzytomnym czy głęboko uśpionym. A jeśli nawet musisz być świadomy, żeby to pomyśleć, nie wynika stąd, że myślisz o sobie jako świadomym ${ }^{21}$.

Abstrahując już od tego, że nie ma chyba nic dalszego od hermeneutycznego spojrzenia niż proponowane przez Nagela spojrzenie „z zewnątrz", nie

\footnotetext{
${ }^{20}$ S. Rosiek, Stowo wstępne, [w:] Wymiary śmierci, dz. cyt., s. 5-6.

${ }^{21}$ T. Nagel, Śmierć, [w:] tenże, Pytania ostateczne, przeł. A. Romaniuk, Fundacja Aletheia, Warszawa 1997, s. 11.
} 
jest do końca jasne, jakiego rodzaju poznanie, czego właściwie zrozumienie miałoby być efektem owego zobrazowania sobie siebie w bezruchu, bez świadomości. Jeśli wyobrażenie ciała i świadomość, że jest ono wyzbyte świadomości, to maksimum ludzkich zdolności w mierzeniu się ze stanem własnej śmierci - to naprawdę niewiele. Wszystko właściwie kończy się na uprzytomnieniu sobie, jak będzie się wówczas wyglądało i, ponownie, nie przekracza granicy zewnętrzności.

Za równie nieprzekonującą, a także, koniec końców, sofizmatyczną, uważam propozycję swoistej „apofatycznej hermeneutyki śmierci” przedstawioną przez Jacka Bielasa w tekście Jak to jest stać się martwym: doświadczenie śmierci-rekonstrukcja i analiza:

Jeżeli twierdzę, że nic z tego, czego do tej pory doświadczyłem, nie było śmiercią, to tym samym określam już jakoś śmierć. Odróżniam ją od wszystkiego, co zostało mi dane, a więc tworzę lub zakładam pewną definicję śmierci, choć ujmuję ją relacyjnie, a konkretnie negatywnie. Mówię, czym śmierć nie jest ${ }^{22}$.

W przypadku tak ujętego „rozumienia” śmierci nie tyle jednak odróżniam ją od wszystkiego, co zostało mi dane, co zakładam tego brak, zaś pustka, jaka powstaje w miejsce usuniętych składników doświadczenia, nie zostaje wypełniona żadną treścią, czyli de facto propozycja ta nie otwiera drogi dla żadnej inteligibilności, pozwala jedynie ponownie jakoś o śmierci mówić. Mówić „ironicznie”, gdyż, podobnie jak w przypadku postulowanych przez Rośka słów wydzielających "trupi odór”, każde zdanie, każde słowo wypowiedziane w takim zaprzeczonym języku wyraża jedynie poznawczą niemoc mówiącego, a także językową nieuchwytność tego, o czym „mówi”.

Znacznie więcej, choć ponownie poza domeną języka i spekulacji, umożliwia koncepcja „Twojej śmierci” przedstawiona, w oparciu o myśl chrześcijańską i filozofię dialogu przez Ireneusza Ziemińskiego w tekście Twoja śmierć. Próba eksplikacji doświadczenia śmierci. Mimo iż nie każdy podzielać musi idealistyczną i uduchowioną perspektywę, która od pewnego momentu zaczyna dominować nad wywodem ${ }^{23}$, osobisty wymiar artykułu Ziemińskiego (pisa-

22 J. Bielas, Jak to jest stać się martwym, dz. cyt., s. 105.

${ }^{23} \mathrm{~Np}$. „Dopiero śmierć jest prawdziwym sprawdzianem miłości - czy jesteśmy w stanie wytrwać razem nie tylko do śmierci, lecz także w obliczu śmierci, w jej bezpośredniej obecności? Czy nasza miłość jest w stanie sprostać próbie ostatecznej, gdy jedno z nas zostaje skazane na zagładę? Co okaże się w tej konfrontacji zwycięskie - czy unicestwiająca moc śmierci, czy może jednak twórcza moc miłości”; albo: „Gotowość do ofiary z własnego życia tkwi w każdym człowieku, a ujawnia się właśnie w obliczu nieuchronności Tw ojej śmierci. Każdy z nas, gdyby mógł to uczynić, oddałby swoje życie za osobę, którą kocha" (I. Ziemiński, Twoja śmierć. Próba eksplikacji doświadczenia śmierci, "Diametros” 2007, nr 11, s. 129-130 i 133, <http://www. diametros.iphils.uj.edu.pl/?pdf=125> [dostęp: 05.01.2012]; podkreślenia oryginalne). Zob. tenże, Drzewo życia. Próba filozoficznej interpretacji śmierci, „Edukacja Humanistyczna” 2007, nr 1, s. $127-138$. 
nego jako poszukiwanie pokrzepienia i próba zrozumienia swoich doświadczeń po utracie bliskiej osoby) pozwala na założenie o obecności w nim szczególnego rodzaju wglądu właściwego świadectwu.

"Zasadniczo śmierć daje się opisać trojako - w pierwszej, drugiej lub trzeciej osobie" 24 - pisze Ziemiński, powielając, choć z pewnymi różnicami, podział zaproponowany przez Vladimira Jankélévitcha ${ }^{25}$. Opis „w trzeciej osobie" ujmuje śmierć innego jako obiektywny fakt w świecie, wobec którego to faktu, jako dotyczącego nie-mnie, zachowana zostaje większa lub mniejsza obojętność. „Obiektywistyczny opis nie może więc mnie pouczyć, czym będzie moja własna śmierć dla mnie; może jedynie uprzytomnić mi, czym moja śmierć będzie dla innych ludzi”26. Śmierć „w pierwszej osobie” jest z kolei poznawczo i językowo niedostępna (Ziemiński podpisuje się w tym aspekcie pod maksymą Epikura, jednak jedynie w jej odsłonie epistemologicznej, nie „pocieszającej”). Własna śmierć jest dla podmiotu „Tajemnicą”, zaś wszelkie jej „przybliżenia”, analogony czy modele (sen, choroba, starość rozumiana jako „kurczenie się przyszłości”) są nie tyle nawet niedoskonałe, co złudne. Dopiero opis „Twojej śmierci”, opis „w drugiej osobie”, sytuujący się pomiędzy dwoma poprzednimi (lub raczej między opisem „w trzeciej osobie" a ideą tego, jak powinien wyglądać opis „w pierwszej osobie”, a czemu żaden opis nie jest w stanie sprostać), pozwala na „uchwycenie rzeczywistej natury śmierci” i jest „uprzywilejowanym doświadczeniem, dzięki któremu jesteśmy w stanie ująć śmierć w jej istocie" 27.

Co ciekawe, podczas gdy Ziemiński neguje możliwość jakiejkolwiek współuczestnicząco-antycypującej hermeneutyki umierania (albowiem „ostatecznie (...) wszelki wysiłek mojej wyobraźni ukazuje nieprzekraczalną barierę ontologiczną między mną a Tobą" ${ }^{28}$ ), o tyle otwiera drogę czemuś znacznie bardziej, zarówno z poznawczej, jak i egzystencjalnej perspektywy, doniosłe$\mathrm{mu}$ - jakąś formę doświadczenia własnej śmierci. W takim bowiem stopniu, w jakim zawiązanie opartej na miłości podmiotowej relacji ja-Ty (w tym sensie, w jakim pisali o tym Martin Buber, Emanuel Lévinas czy Józef Tischner) jest powołaniem do życia nowego bytu - „My", „Nas" - w takim

Twoja śmierć okazuje się, przynajmniej częściowo, moim umieraniem (...). Ja wprawdzie nie umieram jako osoba fizyczna, umieram jednak jako jeden z podmiotów relacji ja-Ty; Twoja śmierć unicestwia więc mnie o tyle, o ile istniałem z Tobą i dla Ciebie ${ }^{29}$.

${ }^{24}$ I. Ziemiński, Twoja śmierć..., dz. cyt., s. 114.

${ }^{25}$ V. Jankélévitch, Tajemnica śmierci i zjawisko śmierci, przeł. S. Cichowicz i J.M. Godzimirski, [w:] Antropologia śmierci..., dz. cyt., s. 64 i n.

${ }^{26}$ I. Ziemiński, Twoja śmierć..., dz. cyt., s. 114.

27 Tamże, s. 116.

28 Tamże, s. 126.

29 Tamże, s. 118-119. 
I dalej: „Twoja śmierć stanowi jedyne (a przynajmniej - najbardziej źródłowe) doświadczenie śmierci jako rzeczywistej nicości" ${ }^{30}$. Śmierć Drugiego / Ciebie stanowi „wtargnięcie nicości” w samo centrum (przeżywanego) świata jednostki.

Podobnie doświadczenie utraty bliskiej osoby opisuje w Wyznaniach święty Augustyn:

Dziwiłem się, że inni śmiertelni ludzie żyją jeszcze, skoro umarł ten, którego tak kochałem, jakby nigdy nie miał umrzeć. A zwłaszcza dziwiłem się, że po jego śmierci żyję ja, który byłem połową jego duszy. Trafnie to ktoś [Horacy - przyp. P.J.] powiedział o przyjacielu: "Połowa duszy mej”. Odczuwałem to tak, że jego i moja dusza były jedną duszą w dwóch ciałach. Dlatego też przerażało mnie życie, bo nie chciałem przez nie kroczyć będąc tylko połową siebie. Może też właśnie dlatego tak bardzo bałem się umrzeć, aby ze mną nie umarł już cały ten, którego tak kochałem³1.

Doświadczenie to otwiera, w przypadku Augustyna, drogę do filozofii osoby: „stałem się sam dla siebie wielkim problemem” ${ }^{32}$, a więc też „problemem, który muszę rozwiązać", albo przynajmniej się z nim zmierzyć; Ziemiński wskazuje jednak, że owo doświadczenie śmierci części-siebie, otrzymane poprzez śmierć kochanej osoby, „leczy z wszelkiej pokusy filozofowania na temat śmierci”. Albowiem „wiedza, którą zyskujemy dzięki śmierci Drugiego, ma charakter głębokiego, osobistego przeżycia egzystencjalnego i jest czymś radykalnie nowym w stosunku do wszystkiego, co wiedzieliśmy wcześniej”33. Nie proponuje i sam nie usiłuje szukać „nowego języka”, którym mógłby to doświadczenie wyrazić, ale raczej, czerpiąc $\mathrm{z}$ „pocieszenia, jakie daje filozofia”, zgadza się na komunikacyjne (transferowe) ograniczenia czy bariery nakładane przez skrajnie indywidualne doświadczenie graniczne.

Wielu badaczy i myślicieli pozostaje zgodnych, że śmierć bliskiej osoby jest uprzywilejowanym sposobem, w jaki możemy poznać / zrozumieć / odczuć własną śmierć, albo coś „,na jej kształt”, albo jakąś jej namiastkę, ponownie obarczoną logicznym paradoksem i niedoskonałą, o ile uznamy, że śmierć miałaby być właśnie nie-odczuwaniem.

Śmierć kogoś nam drogiego - pisze Vladimir Jankélévitch - jest prawie jakby naszą śmiercią, prawie tak rozdzierającą jak nasza własna (...) i w pewien szczególny sposób jest rzeczywiście śmiercią własną; ten, którego nie sposób pocieszyć, opłakuje tutaj tego, kogo nie sposób zastąpićín

30 Tamże, s. 127.

31 Św. Augustyn, Wyznania, przeł. Z. Kubiak, De Agostini, Warszawa 2001, księga IV, p. 6 .

32 Tamże, księga IV, p. 4.

${ }^{33}$ I. Ziemiński, Twoja śmierć..., dz. cyt., s. 120.

${ }^{34}$ V. Jankélévitch, Tajemnica śmierci..., dz. cyt., s. 69. 
Myśl tę rozwija Louis-Vincent Thomas, pisząc, praktycznie unisono z Jankélévitchem, że:

Śmierć kogoś drugiego nie tylko przypomina mi, że ja także muszę umrzeć - jest ona po trosze moją własną śmiercią. Jest moją śmiercią tym bardziej, im bardziej ten drugi był dla mnie kimś wyjątkowym i niezastąpionym (...). Umierając, druga osoba umiera już moją śmierciąa

Thomas odwołuje się tu do relacyjnej i ekspozycyjnej strony tożsamości jako istotnego komponentu egzystencjalnego jednostki ${ }^{36}$. Wprowadzone przez George'a Meada pojęcie „znaczącego innego" dotyczy raczej procesu pierwotnej socjalizacji, można jednak, jak sądzę, mówić o Drugim, bliskim czy „Ty” („Tobie”) z filozofii dialogu jako właśnie swoistego rodzaju „znaczącym innym", to znaczy tym, jak to się określa, „w czyjego oczach się przeglądamy", czyje zdanie na temat naszych słów i działań uznajemy za istotne (prawdziwe), komu przyznajemy (par excellence hermeneutyczne) prawo do „rozumienia nas lepiej, niż sami siebie rozumiemy”, kto stanowi usankcjonowanego arbitra naszych postępków i swoisty imperatyw działania nawet w sytuacji jego nieobecności (chcę postępować w sposób, który on by zaakceptował, gdyby widział moje postępowanie), wreszcie tego, wobec i dla którego naruszona zostaje, na tyle, na ile to możliwe, ontologiczna monadyczność jednostki („,cząstki elementarnej”, jak to określił Michael Houellebecq) poprzez „otwierające" uczucia, takie jak bliskość, zażyłość, empatia czy troska. Śmierć takiej osoby, podobnie jak jej życie, stanowi „istotną determinantę tworzenia przeżyć uczuciowych każdego człowieka" ${ }^{37}$.

Jednak kiedy w końcowej części swojego tekstu Thomas próbuje określić "treść" zmiany, jaka następuje wskutek doświadczenia „po trosze” czy „prawie" własnej śmierci poprzez śmierć bliskiej osoby, pisze, że:

Różnorodność sytuacji [śmierci - przyp. P.J.], ulotność związanych z nimi sensów nie pozwala nam właściwie na wyciągnięcie żadnych wniosków. W końcu doświadczenie naszej śmierci, tak jak doświadczenie śmierci kogoś drugiego, mówi nam bar-

35 J.-V. Thomas, Doświadczenie śmierci..., dz. cyt., s. 170.

${ }^{36} \mathrm{Na}$ temat ekspozycyjnej i relacyjnej strony tożsamości zob.: A. Cavarero, Opowiedz mi moją historię, przeł. A. Klimczak, „Pamiętnik Literacki” 2004, z. 3, zwłaszcza strony 16-21.

37 J.-V. Thomas, Doświadczenie śmierci..., dz. cyt., s. 171-172. „Ostatecznie bowiem jestem osobą tylko wtedy, gdy jestem zdolny do owego wzajemnego, dokonującego się we mnie komunikowania, które jest istnieniem. Śmierć [bliskiego - przyp. P.J.] okazuje się zatem niemożliwością owego wewnętrznego, we mnie zachodzącego komunikowania, zniknięciem mnie jako jakiejś świadomości" (R. Mehl, Le vieillissement et la mort, cyt. za: tamże, s. 170). W podobnym duchu wypowiada się też Władysław Stróżewski: „Śmierć drugiego umniejsza także $\mathrm{w}$ jakiś sposób nas samych. Realna relacja, w jakiej pozostawaliśmy wobec drugiego, traci sens, znika. To, co bogaciło nas, gdy staliśmy twarzą $\mathrm{w}$ twarz wobec niego, co bogaciło nas na co dzień dzięki obcowaniu z nim, należy już do przeszłości. Może dopiero wtedy widzimy, jak wiele zawdzięczamy innym, jak bardzo współkonstytuuje nas stosunek ja-ty" (tamże, s. 141). 
dzo niewiele o śmierci jako takiej [podkr. - P.J.], a jeśli już - to o jej godnej uwagi mocy wywoływania zaburzeń, a zatem, w następstwie, przekształceń ${ }^{38}$.

Uzupełnienia tego aspektu dostarczyć z kolei może Jankélévitch, przywołujący Platońskie pojęcie anamnezy (anamnesis), czyli wiedzy wrodzonej, która następnie zostaje utajona / zapomniana, w efekcie czego poznanie jej nie jest poznaniem czegoś nowego, lecz roz-poznaniem. Cały tekst Jankélévitcha oparty jest na, jak by to powiedział Rosiek, „błyskotliwym paradoksie”. Jak to możliwe, że śmierć jest jednocześnie czymś tak powszechnym i bliskim, jak i czymś tak nie-swoim i obcym? Śmierć jest - jak pisze badacz - „Dziwna, a jednak tak swojska, że nawet najbardziej tępy człowiek rozpoznaje ją, pojmuje [podkr. - P.J.] i oddaje jej hołd natychmiast, gdy tylko ją spotka. Taka jest właśnie owa (...) naturalna nadnaturalność śmierci ${ }^{39}$.

Jankélévitch pojęcia anamnezy używa wobec momentu uświadomienia sobie własnej śmiertelności:

Pewnego pięknego dnia - pisze - [człowiek - przyp. P.J.] uzmysławia sobie coś, o czym wiedział już od dawna: to uświadomienie jest najczęściej jakąś nagłą intuicją (...). Można wyobrazić sobie osobisty dziennik, w którym mędrzec zanotowałby: tego ranka, 21 listopada, o godzinie trzynastej trzydzieści pięć, dowiedziałem się w końcu, że człowiek musi umrzećt ${ }^{4}$.

Efektem jest jednak radykalne przeformułowanie wszystkiego, co „śmiertelnik" do tej pory myślał, że wiedział w tej kwestii. Owo przypomnienie z różnicą, jest „nowe, pierwotne, oryginalne (...), od chwili, kiedy się dowiedzieliśmy, wydaje nam się, iż nie wiedzieliśmy nigdy przedtem, a nasza dawna wiedza zdaje nam się tak odległa, jak jakaś nauka prenatalna, tak pusta jak niewiedza"41.

Zastanówmy się jednak, czy tego, co Jankélévitch pisze o fakcie śmiertelności, nie można odnieść też do momentu umierania. Absolutna nowość, jaką jest moment umierania, domaga się absolutnie nowej jakości. Podobnie jak $\mathrm{w}$ tradycyjnych rites de passage należało dostarczyć aspirantowi wyrazistych bodźców pod postacią bólu, przerażenia czy oszołomienia, by - być może zamaskować owe „nic” czy „niewiele”, które wbrew temu, co świadomości podsuwa kultura i język, odbiera ciało po przejściu na „drugą stronę", tak też i w kwestii śmierci oczekiwanie jakościowo absolutnego novum jest - ponownie: być może - jedynie konsekwencją przyjęcia przez świadomość pewnych założeń, naprawdę zaś, tak jak w przypadku wielu egzystencjalnych „debiutów", składa się z konglomeratu dobrze już poznanych emotywnych jakości, jakkolwiek niechciane by one nie były.

\footnotetext{
38 Tamże, s. 178.

${ }^{39}$ V. Jankélévitch, Tajemnica śmierci..., dz. cyt., s. 47.

40 Tamże, s. 54.

41 Tamże, s. 53.
} 
Wielu badaczy zastanawia się nad specyficznym statusem wiedzy o pewności swojej śmierci. Freud, jak już wspomniałem, do rozwikłania tego paradoksu dokonać musiał rozdzielenia konstytucji psychicznej jednostki na poinformowaną o śmierci świadomość i podtrzymującą przekonanie o nieśmiertelności nieświadomość. „Śmierć jest przyszłością, która nigdy nie nadchodzi" - pisze Jankélévitch ${ }^{42}$, nazywając, w innym miejscu, śmierć „niezdeterminowanym zdeterminowaniem" ${ }^{43}$, jakby tylko język paradoksu mógł pochwycić doksa śmiertelności. „Podczas całego mojego życia mogę ostatecznie tylko wierzyć w moją śmierć" ${ }^{44}$ - pisze z kolei Michel de Certeau, co skłania do przyjęcia jako analogii świadomości śmierci takiego nastawienia opartego na wiedzy-wierze czy ufności, jakie cechuje odniesienie do proroctwa lub przepowiedni.

Dwa podstawowe modele wyjaśniają ów stosunek: pierwszym z nich jest różnica między informacją a przekonaniem, drugim - między przekonaniem a momentem realizacji tego, co do czego jest się przekonanym. Pierwszy obrazowałoby twierdzenie „może jednak nie...", drugi - „może jeszcze nie teraz...”. Oba te modele, jak sądzę, współdziałają ze sobą, nawzajem uzupełniając swoje słabe punkty. Pierwszy jest (w przypadku śmierci) naiwny, drugi - tymczasowy. Przekonanie charakterystyczne dla modelu pierwszego dotyczyć jednak może, bardziej zasadnie, również takich rzeczy, które "się zdarzają”, ale niekoniecznie muszą się przytrafić konkretnej osobie: ciężka choroba, wypadek, śmierć kogoś bliskiego, zagrożenie życia wskutek napadu czy wojny itd. Rezydują one jakby w puli „zagrożen”", gdzieś „z tyłu” świadomości. Idąc nieoświetloną ulicą wieczorową porą, jadąc autem w złych warunkach drogowych, zauważając u siebie niepokojące symptomy, zagrożenia owe stają się poniekąd bardziej możliwe, realniejsze, jednak, jak się zdaje, aż do samego końca mają zdolność do zachowywania właściwej sobie szansy / nadziei niespełnienia: „może jednak nie”. Kiedy ta jednak zawodzi, wówczas następuje w świadomości właśnie coś w rodzaju rozpoznania. Anamneza właściwa

42 Tamże, s. 58.

43 Przypominając, że podstawowy przykład rozumowania dedukcyjnego mówi wszak o śmierci ludzkiej (skoro wszyscy ludzie są śmiertelni, a Sokrates jest człowiekiem, znaczy to, że Sokrates jest śmiertelny, a więc - Sokrates umrze), Jankélévitch wskazuje, że „działa” on (ów schemat) jedynie w przypadku, gdy tym, o kim się wnioskuje, jest ktoś inny (ktoś „w osobie trzeciej”), "jakiś Sokrates”. Zawodzi zaś zupełnie, jeśli odnieść go do samego siebie. „Wiem, że umrę, ale w głębi duszy nie jestem o tym przekonany” - pisze Jankélévitch. „Można by rzec, że na próżno nieustannie konstatowano śmiertelność śmiertelników, na próżno potwierdzały to miliony śmierci indywidualnych, na próżno wszystkie życia, jak świat światem, nieuchronnie i niezmiennie kończyły się triumfem śmierci - ta niezwyciężoność śmierci, tak bogato, a nawet do przesady poświadczana, wymaga jeszcze jakiegoś dowodu dodatkowego. (...) Czyjaś realna śmierć (...) zawsze wnosi element nowości i zaskoczenia" (tamże, s. 51-52).

${ }^{44}$ M. de Certeau, To, co nienazywalne: umieranie, [w:] tenże, Wynaleźć codzienność. Sztuki działania, tłum. K. Thiel-Jańczuk, Wydawnictwo UJ, Kraków 2008. 
umieraniu, jako paradygmatycznemu momentowi „a jednak tak”, w niczym nie byłaby podobna do prostego przypomnienia sobie czegoś, co zostało zapomniane lub strukturalnie przesłonięte, nie byłaby wrażeniem w rodzaju „no właśnie!”, „no przecież!”, raczej stanowiłaby ten rodzaj „pierwotnego przypomnienia", jako cechuje wcielanie wiedzy w życie, teorii w praktyke, uwewnętrznienie tego, co do tej pory było zewnętrzne, odgrywanie naprawdę czegoś, co wcześniej było jedynie możliwością roli. Człowiek - pisze Jankélévitch - styka się ze śmiercią, „improwizując” 45 , i mimo całej „beznadziei”, która wiąże się z uświadomieniem sobie swojego położenia („teraz ja”, „teraz moja kolej”), kiedy ewentualność staje się ewenementem, umierający może „improwizować”, bo zna już śmierć - by trwać przy muzycznych metaforach - jako motyw przewodni, i dysponuje znaną, ograniczoną pulą możliwych środków wyrazu. W śmierci, podobnie jak w języku, powszechne prawo (uzus) odbija się w jednostkowej realizacji (idiom). Poznanie, będące rozpoznaniem siebie jako przypadku podlegającemu nieuchronności ogólnego prawa, przebiegać zaś może w dwóch etapach: najpierw „jestem śmiertelny” (intuicja), potem - „umieram” (świadomość).

Gotowość na przyjęcie doświadczenia śmierci, właściwe jej elementy, jej „posmak”, przynależałyby więc w znacznej mierze do immanencji człowieka (Stróżewski, poruszając analogiczny wątek, odwołuje się do zaczerpniętej od Rilkego metafory śmierci jako pestki, którą człowiek, jak owoc, w sobie nosi, i która razem z nim rośnie i dojrzewa $\left.{ }^{46}\right)$. Śmierć zaś nie byłaby, jak chciał Bielas, zanegowaniem wszystkiego, co znamy, ale wręcz przeciwnie - czymś znajomym i swojskim, jakby - mimo faktu, że każdy „umiera jako pierwszy” - już wielokrotnie przeżytym, a to dzięki dwojakiego rodzaju przyczynom: po pierwsze, anamnesis (w rozszerzonym, względem Jankélévitcha, ujęciu, które powyżej przedstawiłem), z jej podstawowym elementem, jakim jest wrażenie nieodwracalności (czasu) charakteryzowane przez bolesne stwierdzenie „a jednak tak”, „stało się” (które dalekim echem odbija „Wykonało się" wypowiedziane przez Jezusa na krzyżu ${ }^{47}$ ), a także, po drugie, antycypującej partycypacji przy umieraniu innego wspieranej kulturową fantazmatyką tanatycznych motywów wypracowaną w literaturze i sztuce.

45 V. Jankélévitch, Tajemnica śmierci..., dz. cyt., s. 60.

46 „Dawniej wiedziano (a może domyślano się), że śmierć człowiek nosi w sobie jak owoc pestkę. Dzieci miały w sobie małą, a dorośli dużą. Kobiety miały ją w łonie, a mężczyźni w piersi. Dość, że się ją miało - a to dawało człowiekowi osobliwą, dostojną i cichą jakąś dumę" (R.M. Rilke, Malte. Pamiętniki Malte-Lauridsa Brigge, przeł. W. Hulewicz, cyt. za: W. Stróżewski, O doświadczeniu śmierci..., dz. cyt., s. 136).

${ }^{47}$ M. Foucault, Język bez końca, przeł. M.P. Markowski, [w:] tenże, Powiedziane, napisane. Szaleństwo i literatura, wybór i oprac. T. Komendant, Fundacja Aletheia, Warszawa 1999, s. 9, 30. 
„Śmierć jest pewnym sposobem bycia” ${ }^{48}$, i dalej „śmierć w najszerszym sensie jest fenomenem życia" ${ }^{49}$ - pisze Martin Heidegger, który śmierci, byciu ku śmierci (Sein-zum-Tode), poświęca osobny rozdział swojego dzieła Bycie i czas. Rozważania o śmierci nie stanowią jednak celu same w sobie, lecz służą filozofowi dla badania możliwości ujęcia całokształtu jestestwa, dla którego to całokształtu śmierć stanowi ukonstytuowanie. Egzystencję cechuje, zdaniem Heideggera, ciągła „niezamkniętość”, określana jako „zaległość” (Ausstand), nieustanna możliwość osiągnięcia / nastąpienia czegoś jeszcze. Śmierć nie jest jednak, jak można by sądzić, kresem wszelkich możliwości, ale ich punktem odniesienia, „najbardziej własną możnością bycia”50, możliwością „nieprześcignioną". Śmierci jako bytowemu azymutowi życia przypisuje bowiem Heidegger dwie podstawowe funkcje: po pierwsze, chroni ona jestestwo przed skostnieniem w osiągniętej aktualnie egzystencji, a zarazem pozwala orientować się w „przypadkowym natłoku możliwości”, właściwie je rozumieć i wybierać te właściwe ${ }^{51}$ (uderzająca jest aktualność myśli Heideggera w kontekście współczesnego „hipermarketu” idei i propozycji tożsamościowych), a także, po drugie, „,bezwzględność śmierci indywidualizuje jestestwo w samym sobie”, śmierć „domaga się go [jestestwa - przyp. P.J.] jako indywidualnego" ${ }^{52}$. Wybieganie ku niej, bycie ku niej, pozwala na przejście od powszechnej "gadaniny” Się (,umiera się", kiedyś tam, gdzieś tam, jeszcze nie, nie "tu-oto" ${ }^{53}$ ) do ujednostkowionego Siebie. Efektem jest jednakże pełne i nieprzesłonione doznanie „wrzucenia” w grozę świata - trwoga (Angst). Osiągnięta w ten sposób wolność od złudzeń „dyktatury Się” przedstawiona zostaje, w opisie Heideggera, ambiwalentnie: jest jednocześnie „pewna samej siebie" i "trwożąca się" ${ }^{\prime \prime}$. Jestestwo osamotnione, zatrwożone w swym i tylko swym byciu ku własnej śmierci, staje się też mocne, gdyż już nie „uchodzi przed nią", ale, odważnie i nonkonformistycznie, egzystuje „ku niej”, dzięki czemu może - w iście nietzscheańskim duchu - przemienić przypadkowe wybory w swą własną konieczność.

\footnotetext{
${ }^{48}$ M. Heidegger, Bycie $i$ czas, dz. cyt., s. 244.

49 Tamże, s. 346.

50 Tamże, s. 352.

51 Tamże, s. 370.

52 Tamże.
}

53 „Analiza owego »umiera się« odsłania niedwuznacznie sposób bycia powszechnego bycia ku śmierci. W takim mówieniu pojmuje się śmierć jako coś nieokreślonego, co ostatecznie musi skądś nadejść, ale co na razie jeszcze się człowiekowi nawet nie uobecniło i dlatego nie jest groźne. (...) Umieranie, które w sposób z istoty nie do zastąpienia jest moje, zostaje obrócone w przytrafiające się owemu Się zdarzenie o charakterze publicznym. (...) Przez taką dwuznaczność jestestwo stawia się w sytuacji, w której swą wyróżnioną, należącą do najbardziej własnego Siebie możnością bycia zatraca się w Się. To Się uzasadnia i wzmacnia pokusę zakrywania najbardziej własnego bycia ku śmierci" (tamże, s. 355-356).

54 Tamże, s. 373. 
Propozycja Heideggera różni się od tych przedstawionych powyżej w dwóch zasadniczych aspektach. Po pierwsze, Heidegger nie stara się w żaden sposób przybliżyć czy uchwycić istoty śmierci, lecz wprowadzić, zza zasłony Się, pewność nieuchronności śmierci w egzystencjalne pole jestestwa i uczynić ów fakt produktywnym. Po drugie, odmawia większej wartości poznawczej „śmierci innego" - perspektywie określonej uprzednio jako antycypująca partycypacja. Z jednej strony filozof wskazuje, że jestestwo poprzez obiektywne zdarzenie śmierci innych „może nabyć doświadczenia śmierci, zwłaszcza że jest z istoty współbyciem z innymi" ${ }^{55}$, z drugiej jednak strata, jaką jest śmierć innego, nie jest zaś w żadnej mierze właściwą temu, kto umarł, stratą związaną z przejściem do „niebycia-tu-oto”, dlatego też: „nie doświadczamy w rzeczywistym sensie umierania innych, co najwyżej im »towarzyszymy «"56. Śmierć, jako najbardziej „własna” możliwość, jest ze swej istoty nie do zastąpienia, nie do scedowania. Umieranie innych, jako „zastępczy temat analizy", zapoznaje ten "egzystencjalny stan rzeczy"57, przyczyniając się, w nie mniejszym stopniu niż powszechne „umieranie Się”, do wydziedziczania jestestwa $\mathrm{z}$ tego, co najbardziej mu przynależne, przesłaniania mu tego, co stanowi jego egzystencjalną istotę ${ }^{58}$.

Zupełnie inaczej na tę kwestię zapatruje się Zygmunt Bauman w książce Śmierć i nieśmiertelność. Jego zdaniem, gdyby nie było śmierci, albo gdyby ludzie nie byli uświadomieni w kwestii swojej śmiertelności, nie byłoby kultury. Kultura nie jest jednakże sposobem „układania się” ze śmiercią, lecz „,antymnemotechnicznym narzędziem do zapominania [podkr. - P.J.] o tym, czego ludzie są świadomi" ${ }^{\prime 2}$. Podjęcie jakiegokolwiek twórczego działania byłoby niemożliwe $\mathrm{w}$ przypadku uświadomionej nieśmiertelności (Bauman przypomina tu opowiadanie Jorge Luisa Borgesa Nieśmiertelny oraz jednego z jego bohaterów, Homera, który nie pisze Odysei, bo, jak wyznaje narratorowi: „,jeśli założymy nieskończony okres czasu, z nieskończonymi okolicznościami i wa-

\footnotetext{
55 Tamże, s. 334-335.

56 Tamże, s. 336.

57 Tamże, s. 338.
}

58 Równie negatywnie, choć z odmiennych pobudek, odnosi się do „śmierci innego” Michel de Certeau: „Wytwarzając obraz umierającego, postępuję właściwie w podobny sposób [tak jak instytucje usuwające go poza obręb społeczeństwa - przyp. P.J.]. Uczestniczę w kłamstwie sytuującym śmierć gdzie indziej, w szpitalu lub w ostatnich chwilach: przekształcam ją w obraz innego; utożsamiając ją z umierającym, czynię z niej miejsce, w którym mnie nie ma" (M. de Certeau, To, co nienazywalne..., dz. cyt., s. 195).

59 Z. Bauman, Śmierć i nieśmiertelność..., dz. cyt., s. 41. Teza Baumana brzmi: „instytucje społeczne i »rozwiązania kulturowe« są osadami procesu, który został pobudzony przez fakt ludzkiej śmiertelności, a motywowany potrzebą radzenia sobie z wywołanymi przez ten fakt problemami; jak też przez równoległą potrzebę stłumienia świadomości prawdziwych motywów takich rozwiązań (tamże, s. 14). 
riantami, jest niemożliwością, by nie napisać Odysei choćby jeden raz" ${ }^{\prime \prime 0}$ ). Jednakże w przeciwnej sytuacji - gdyby śmiercionośny miecz Damoklesa wisiał nad człowiekiem cały czas i na zbyt cienkim włosiu - podejmowanie twórczych działań również zdawałoby się bezcelowe. Wszelkie projekty, zamierzenia, starania muszą usunąć możliwość śmierci z kalkulacji (chyba że, jak w przypadku Opałka 1965 /1 - $\infty$ Romana Opałki, zintegrują ją jako swój element), w niektórych wypadkach zaś warunkiem ich podjęcia jest zapomnienie, że zakrojone są na skalę szerszą niż możliwa długość życia jednostki ${ }^{61}$. Kultura, zdaniem Baumana, ma moc utrzymywania w równowadze i twórczego wykorzystywania tego niepamiętania, które nie jest zapomnieniem.

Na koniec chciałbym powrócić raz jeszcze do kwestii śmierci i języka, tym razem jednak $\mathrm{w}$ odmiennym aspekcie: śmierci czy stosunku do niej wpisanych w samą ontologię języka.

Cytowany już Michel de Certeau w swoim krótkim, acz niezwykle wnikliwym i "gęstym" tekście To, co nienazywalne: umieranie, rozpoczyna refleksję nad śmiercią z dwóch uzupełniających się punktów widzenia: psychoanalitycznego (zgodnie z którym konstytucja psychiczna podmiotu wyraża się $\mathrm{w}$ jego stosunku do własnej śmierci) oraz socjologicznym (analogiczne przekonanie, w którym w miejsce "podmiotu" należy wpisać "społeczeństwo", przekonanie połączone $\mathrm{z}$ wszelakimi praktykami usuwania śmierci i umierającego, jako nieużytków, z przestrzeni publicznej).

Wypracowany w nowoczesności język ma charakter technokratyczny, podporządkowany raportowaniu działań podejmowanych w ramach pracy i postępu. Zachód - pisze de Certeau - snuje „opowieść o tym, że »zawsze jest coś do zrobienia «". Umierający zaś jest „lapsusem” tejże historii ${ }^{62}$. Spotyka go ten sam los, co odpady, szaleńców, kaleki czy przestępców. Wyłączony z łańcucha produkcji i konsumpcji, zamknięty zostaje w izolujących instytucjach (szpitale, więzienia, wysypiska), które, na opłotkach społecznego życia, skrywają i przetwarzają elementy "obsceniczne”: nienadające się do „wyniesienia na powierzchnię postępu" i zagrażające wszystkim tym, którzy zintenalizowali i respektują panujące tam prawa.

${ }^{60}$ J.L. Borges, Nieśmiertelny, przeł. A. Sobol-Jurczykowski, [w:] tenże, Opowiadania, Wydawnictwo Literackie, Kraków 1978, s. 171.

${ }^{61}$ Jest coś niestosownego w tym, kiedy ktoś umiera, nie dokończywszy swego dzieła (pisarz $\mathrm{w}$ połowie pisanej książki, aktor w trakcie zdjęć do filmu itp.), jakby właściwym czasem dla śmierci był moment zastoju, interwał między działaniami, albo jakby samo działanie miało śmierć odsuwać, czynić ją mniej prawdopodobną (mniej możliwą) niż podczas bezczynności. Jean Améry tak pisał o skandalu, jakim była przedwczesna śmierć Franza Kafki: „Gdy Kafka odszedł w wieku 41 lat, literackie sumienie świata wzburzył taki upokarzający triumf natury, która nic o sobie nie wie [podkr. - P.J.]" (J. Améry, Podnieść na siebie rękę. Dyskurs o dobrowolnej śmierci, [w:] tenże, O starzeniu się. Podnieść na siebie rękę, przeł. B. Baran, Czytelnik, Warszawa 2007, s. 163).

${ }^{62}$ M. de Certeau, To, co nienazywalne..., dz. cyt., s. 192. 
Szpital, w którym zamyka się umierającego, nie tylko odmawia mu pełnej podmiotowości, ale też traktuje go jako dodatkowe zagrożenie, tym razem dla swojej misji. Wyabstrahowuje z niego medyczny element nazwany "chorobą" i to na walce z nią skupia swoje siły: „leczyć oznacza wyzdrowieć”. Gdyby padło zakazane słowo - „umieram” - instytucja szpitala nie tylko musiałaby uznać swoją porażkę, ale też zmierzyć się z problemem komunikacji z przeciwnikiem tak silnym, że zdolny był ją (instytucję) pokonać, a jednocześnie tak słabym, że pozbawionym nawet języka ${ }^{63}$.

Wykluczeniu z pola przestrzeni publicznej, z pola tego, co „widzialne, i tego, co „uznane”, towarzyszy więc wykluczenie z języka. „Śmierć jest innym miejscem" ${ }^{64}$ nie tylko pola praktyk, nie tylko przestrzeni dyskursywnej, ale i semantyki: $w$ społecznej sferze znaczeń to, co pojmowalne, pokrywa się z tym, co produktywne, zaś „znaczenie (czegoś)” stało się „znaczeniem dla (czegoś)".

Jak każde „wyparte”, śmierć powraca, ale powraca „w przebraniu”, w zmarginalizowanych językach: „religijnych, szatańskich, magicznych czy fantastycznych repertuarach" ${ }^{65}$, w które nikt już nie wierzy, a mimo to ceduje na nie obowiązek wyrażenia tego, co niewyrażalne, czyli umierania. Tymczasem, jak twierdzi de Certeau, powołując się na „pytanie Edypa”, znaczenie owego wypowiedzenia jest, z punktu widzenia tożsamości i samorozumienia, zasadnicze: „Czy rzeczywiście dopiero wówczas, gdy jestem nikim, zaczynam stawać się prawdziwie człowiekiem” ${ }^{\prime 6}$. Na przeszkodzie możliwości wypowiedzenia tej „prawdy” stoi jednak potrójna armia milczenia: instytucji, potocznego języka i podmiotu. Niewypowiedziane umieranie równe jest - de Certeau odnosi się tu do wiersza Borisa Viana - „zdychaniu na śmietniku”. Umierającemu wystarczyłoby "samo miejsce w języku innego", jednakże nawet tego, w efekcie praktyk odizolowywania, mu się „odmawia" ${ }^{67}$. To, co nie może zostać wypowiedziane i usłyszane, czyli śmierć, może jednak - pisze de Certeau - zostać zapisane, i w czystym piśmie bez głosu odnaleźć swój „język”. Referencja - przedstawianie pismem - jest jedynie, jak to określił Paul de Man, tegoż pisma złudzeniem, lub - to już stwierdzenie de Certeau - „odpadem”. Zasadą pisma jest brak, niemożliwa adekwatność rzeczy i znaku, odebrana znakowi obecność: „Pismo powtarza ów brak za pomocą wszystkich swoich znaków

${ }^{63}$ Dodać należy, że de Certeau pisał swój tekst w czasach, kiedy instytucje „uznanego" umierania, takie jak hospicja czy oddziały medycyny paliatywnej, należały do rzadkości - Cicely Saunders pierwszą tego typu placówkę, londyńskie Hospicjum Świętego Krzysztofa, otworzyła w 1967 roku; książka de Certeau została wydana w roku 1980.

${ }^{64}$ M. de Certeau, To, co nienazywalne..., dz. cyt., s. 193.

65 Tamże.

66 Tamże.

67 Tamże, s. 194. 
graficznych będących pamiątkami marszu przez język" ${ }^{68}$. Ta „unieobecniająca” praca pisma zatrzymuje się na chwilę przy spotkaniu z jedyną dostępną zewnętrznością, jaką jest „odbiorca przybywający skądś, oczekiwany, lecz nigdy nie słyszany, gość na piśmiennych drogach" ${ }^{69}$. Absolutna powierzchniowość pisma operuje więc między dwoma obecnościami - tego, który pisze, i tego, który czyta; oni nawzajem - jak pisze de Certeau - „dają sobie znak" (w zupełnie dosłownym sensie dawania / darowania), którego jedynym znaczeniem jest wołanie: „tęsknię do ciebie"70. Treścią pisma jest więc śmierć, zaś „pisarz jest (...) umierającym, który pragnie przemówić"71.

W tej metafizycznej ontologii języka widać inspirację zarówno słynnym zdaniem Ferdynada de Saussure'a o języku jako „systemie różnic bez składników pozytywnych"72, jak i esejem Michela Foucaulta Język bez końca z 1963 roku, w którym również naszkicowane są relacje łączące pismo i śmierć. „Być może jest tak - pisze Foucault - że zbliżanie się śmierci, jej władczy gest, którym wkrada się do ludzkiej pamięci, drąży w istnieniu i teraźniejszości pustkę, z wnętrza której i ku której kierujemy swe słowa"73. Foucault uwspółcześnia myśl Homera, zgodnie z którą nieszczęścia są darem zsyłanym przez bogów na ludzi, by ci mieli o czym opowiadać, ludzie zaś - w zaiste „taktyczny" sposób, zgodnie z rozumieniem tego terminu przez de Certeau ${ }^{74}$ - opowiadają po to, by nieszczęścia te od siebie odsunąć. W tym językowym odraczaniu, opowieści nie są już przede wszystkim opowieściami o zdarzeniach, lecz opowieściami o opowieściach. Język, uciekając przed śmiercią, z której się wywodzi, „zwraca się ku sobie; napotyka tam zwierciadło i, by powstrzymać śmierć, może zrobić tylko jedno: zrodzić w głębi siebie swój własny obraz w nieskończonej grze luster"75. Język to metajęzyk, co widać już na poziomie zapisania (,pismo alfabetyczne (...) nie przedstawia znaczącego, lecz elementy fonetyczne, które je oznaczają"76), a czego pewne formy podwojenia, takie jak stylizacja, pastisz, gry słowne, autoreferencja czy ironia (stanowiące pod-

68 Tamże, s. 195.

69 Tamże, s. 196.

70 Tamże, s. 194.

71 Tamże, s. 199.

72 „W języku istnieją tylko różnice bez składników pozytywnych. Czy weźmiemy element znaczący czy znaczony, język nie zawiera ani wyobrażeń, ani dźwięków, które istniałyby przed systemem językowym, lecz tylko różnice pojęciowe i różnice dźwiękowe wypływające z tego systemu" (F. de Saussure, Kurs językoznawstwa ogólnego, przeł. K. Kasprzyk, Państwowe Wydawnictwo Naukowe, Warszawa 1961, s. 128).

${ }^{73}$ M. Foucault, Język bez końca, dz. cyt., s. 67.

${ }^{74}$ Zgodnie ze słynną opozycją ukutą przez de Certeau, strategia to odgórnie narzucony sposób postępowania, taktyka zaś to podmiotowe przechwycenie go i wykorzystanie we własnym interesie.

75 M. Foucault, Język bez końca, dz. cyt., s. 68.

76 Tamże, s. 69. 
stawowe figury literatury, w której język - by zacytować słynne stwierdzenie Stefana Mallarmégo - „przestał znaczyć, a zaczął być”, obwieszczając tym samym koniec paradygmatu wędrującego po dziedzińcu zwierciadła, a początek dominacji mise en abyme: zwierciadła odbijającego w nieskończoność swoje odbicie), stanowią jedynie potwierdzenie.

W powieści Williama Faulknera Dzikie palmy bohaterowie biorą pod rękę kobietę, która wypiła truciznę, i spacerują z nią przez bar, zmuszając ją do mówienia, mówienia czegokolwiek, choćby nawet bezładnie i bez sensu, by $\mathrm{w}$ ten sposób nie pozwolić jej umrzeć, jakby miejsce dla śmierci otwierało się jedynie $\mathrm{w}$ inercji, przestoju między czynem czy słowem, jakby śmierć nie miała prawa nadejść „w pół słowa”.

I o ile dawnym symbolem osiąganej w języku i poprzez język nieśmiertelności był Sokrates, który przed zażyciem cykuty wypowiedział słowa chwały, słowa godne nieśmiertelności, wzniósł w mowie pomnik „trwalszy niźli ze spiżu", o tyle wraz z nastaniem współczesnej literatury będzie nim już mamrotanie otrutej kobiety, obrazujące „ciągłą i monotonną linię języka skupionego na samym sobie, języka skazanego na nieskończoność ze względu na niemożność oparcia się na nieskończonym słowie"77.

Mówić, by nie umrzeć - pisze Foucault, ale przecież (to już Giorgio Agamben) skoro w języku zaimkowi „ja” (I, je, Ich) nie odpowiada żadne leksykalne znaczenie, skoro „ja” nic poza samym aktem wypowiadania nie znaczy, mówić to tak jakby nie żyć, to znaczy: dekretować swą niemożliwość obecności w języku. Stąd, być może, owo charakterystyczne podwojenie w dokumentach kładących silny nacisk na akt woli czy świadectwo: „ja, »imię«i »nazwisko «", , ja, niżej podpisany".

W książce Co zostaje z Auschwitz, rozwijającej wcześniejsze dzieło Agambena Il linguaggio e la morte (Język i śmierć), włoski filozof mierzy się ze słynną myślą przedstawioną przez Primo Leviego w eseju Pogrą̇̇eni i ocaleni dotyczącą możliwości, a raczej niemożliwości, mówienia o Zagładzie. Jak pisze Levi:

To nie my, którzy przeżyliśmy, jesteśmy prawdziwymi świadkami. (...) O rozbiciu osobowości doprowadzonym do końca, dziele w pełni dokonanym, nie opowiedział nikt, tak jak nikt nigdy nie wrócił, żeby opowiedzieć o swojej śmierci. Ci pogrążeni [muzułmanie - przyp. P.J.], nawet gdyby mieli pod ręką papier i pióro, nie daliby świadectwa, gdyż ich śmierć zaczęła się wcześniej ${ }^{78}$.

Agamben niezwykle surowo ocenia tych, którzy po prostu konstatują niewypowiadalność czy nieopowiadalność tego, co zdarzyło się w Auschwitz, tego, co wcielenie w życie nazistowskiej ideologii zrobiło wówczas ze śmiercią: „jeżeli (...), utożsamiając wyjątkowość z niewypowiadalnością, czynią

77 Tamże, s. 79.

78 P. Levi, Pogrążeni i ocaleni, przeł. S. Kasprzysiak, Wydawnictwo Literackie, Kraków 2007, s. $100-101$. 
[oni - przyp. P.J.] z Auschwitz rzeczywistość całkowicie odrębną od języka, jeśli przecinają relację łączącą w osobie muzułmana niemożliwość z możliwością mówienia, która konstytuuje świadectwo, to powtarzają bezwiednie gest samych nazistów ${ }^{\prime \prime 79}$. Ów gest nazistów odzwierciedlony jest w słowach jednego z obozowych komendantów, wypowiedzianych do nowo przybyłych więźniów. Komendant ów stwierdził, że o tym, co się wydarzy w obozie, nikt się nie dowie, nie będzie bowiem nikogo, kto miałby o tym opowiedzieć, zaś jeśli komuś jakimś cudem udałoby się przeżyć i wydostać się, by mówić, i tak nikt mu nie uwierzy. Przemowa ta uderzyła w najczulszy punkt, w ostatnie źródło nadziei: nie tyle i nie tylko zadekretowała "nie przetrwacie”, ale też „nie przetrwacie w języku”. Ponadto słowa komendanta potwierdzają coś, co jest zasadniczą tezą wielu krytyków zajmujących się literaturą poholokaustową: to, co się wówczas wydarzyło (z perspektywy komendanta i więźniów: wydarzy), jest zbyt przerażające, zbyt nieludzkie, zbyt bolesne, by znaleźć dla tego miejsce w języku. Agamben zaś odpowiada: jeśli język rozumieć będziemy na zasadzie wymiany, to owszem, zgoda; jeśli jednak pojmiemy go jako „dzianie się", jako „wydarzanie się podmiotowości”80, otwarta zostanie szansa świadectwa.

Skoro w samym wypowiedzeniu swojego mówienia (,,ja mówię") ${ }^{81}$ tkwi nieusuwalna sprzeczność (, ja mówię" znaczy „to nie »ja « mówię" lub „»ja« nie może mówić"), słabość ponownie daje się obrócić w atut: niemożność mówienia wpisana jest już w sam akt mówienia. Paradoks ten, występujący w wielu wydaniach (np. narracja w czasie teraźniejszym jest, logicznie, niemożliwa, narracja w czasie przeszłym jest z konieczności zafałszowana), rozwiązuje naświetloną przez Leviego aporię świadectwa. Jeżeli świadek, mówiący „w imieniu” muzułmanina, który głosu jest pozbawiony, „mówi jedynie w oparciu o niemożliwość mówienia, to dawane przezeń świadectwo nie może zostać zanegowane" 82 . Dając świadectwo, mówię „z upoważnienia” tego, który, umierając, zamilkł i nie może wypowiedzieć swojej niemożności mówienia.

Agamben przedstawia, odwołując się do prawa rzymskiego, łaciny i greki, trzy znaczenia słowa „świadek”. Świadek jako testis, oznacza osobę trzecią występującą w sporze między dwoma podmiotami. Świadek jako superstes,

\footnotetext{
${ }^{79}$ G. Agamben, Co zostaje z Auschwitz..., dz. cyt., s. 158.

80 Tamże, s. 165.

81 „Poważne potraktowanie wypowiedzi ja mówię oznacza w istocie zarzucenie badań nad językiem jako środkiem komunikowania sensu czy prawdy przez jakiś podmiot do tego uprawniony i za nie odpowiedzialny (...) Z chwilą, gdy głównym przedmiotem badań stają się wypowiedzi, podmiot wyzbywa się wszelkiej substancjalności i sprawczości, stając się czystą funkcją bądź czystą pozycją" (tamże, s. 142).

82 Tamże, s. 165
} 
to ten, kto przeżył jakieś zdarzenie i może o nim opowiedzieć (odwołując się do tego typu świadectwa, odmawia się istnienia opowieści o Auschwitz, skoro pełne przeżycie tego, co wówczas się działo, oznacza właśnie nieprzeżycie). Jest jednak też trzecie znaczenie - świadek jako auctor. Początkowo słowo to oznaczało osobę, która występowała w zastępstwie (najczęściej osób niepełnoletnich), na zasadzie reprezentowania ich, ale także - sprzedawcę i doradcę. Co łączy auctora jako jednocześnie świadka, sprzedawcę i doradcę? - zastanawia się Agamben, i odpowiada: uzupełnianie tego, czego brak. Sprzedawca nie może niczego sprzedać dopóty, dopóki nie zaistnieje wspólnota woli z tym, kto kupuje. Doradca to ten, który swym działaniem zmierza do ukonstytuowania się właśnie owej wspólnej woli. „Czynność auctora - pisze Agamben - która miałaby samoistną ważność, jest nonsensem". Dlatego też w przypadku auctora jako świadka, jego świadectwo „jest prawdziwe i ma rację bytu jedynie pod warunkiem, że zostaje dopełnione przez tego, kto nie może dać świadectwa" ${ }^{\prime 3}$.

Czy więc, skoro, jak chciał Freud, ilekroć wyobrażamy sobie własną śmierć, odkrywamy, że "przeżywamy samych siebie jako świadkowie” [podkr. - P.J.], i mamy też, jako świadkowie właśnie, możliwość przeżycia śmierci innych, to właśnie ta droga, którą kroczył na przykład David Rieff, świadek umierania swojej matki, Susan Sontag ${ }^{84}$, droga, która w pełni realizuje przedstawione przez Agambena za-danie świadectwa, nie jest właśnie owym „uprzywilejowanym sposobem” poznania tego, czym jest śmierć? Poznania, w którym egoizm i niedoskonałości antycypującej partycypacji zrekompensowane będą przez łaskawość słowa?

Pytanie, na które odpowiedzią jest książka Agambena - jak mówić o czymś, czego się nie przeżyło (w sensie: doświadczyło) i jak mówić o czymś, czego nie przeżył (w sensie: uszedł z życiem) ktoś inny - jest też podstawowym pytaniem naszkicowanego wcześniej hermeneutyki umierania. W ramach konkluzji przedstawić chciałbym hasłowo na razie potraktowany postulat odejścia od naiwnych wyobrażeń i ciągłego dekretowania poznawczej niemocy, mnożenia paradoksów i szukania analogii, w stronę podmiotowo zorientowanych badań nad językiem (w tym językiem „pochwyconym” w literaturze), nad jego ontologią i egzystencjalnym znaczeniem. Odejście od języka rozumianego jako narzędzie relacjonowania, w stronę języka jako praktyki relacjowania.

83 Tamże, s. 151.

84 Zob. D. Rieff, W morzu śmierci. Wspomnienia syna, przeł. A. Nowakowska, Wydawnictwo Czarne, Wołowiec 2009. 


\section{The hermeneutics of dying}

\section{Sum mary}

According to narrative theories (both in literary criticism and in philosophical or psychological applications of the concept of narrative) the end of a story or life story, i.e. its closure, is an essential part of life which provides coherence and meaning to it as a whole. Since human life ends with death, it is important to consider the means of approaching this significant dividing line from the point of view of a living person. While reading the works of French "thanatologists" (e.g. Louis-Vincent Thomas or Vladimir Jankélévitch) as well as the works of Martin Heidegger, Michel de Certeau, Zygmunt Bauman or Giorgio Agamben, the author tries to answer the question: How can dying be understood and included, by anticipation, into one's life story in order to complement it? 